\title{
Optimization of Cutting Process of Medium Density Fibreboards by the Abrasive Water-Jet
}

\section{Optimizacija procesa rezanja ploča vlaknatica srednje gustoće abrazivnim vodenim mlazom}

\author{
Original scientific paper • Izvorni znanstveni rad \\ Received-prispjelo: 29. 3. 2011. \\ Accepted-prihvaćeno: 22. 11. 2011. \\ UDK: $630 * 823.2 ; 630 * 863.312$ \\ doi: $10.5552 /$ drind.2011.1113
}

\begin{abstract}
This paper deals with the process of MDF cutting by the abrasive water-jet (WJC) and shows how is kerf width influenced by process parameters. It presents the results of monitoring the kerf width related to technical and technological parameters, material parameters and cutting method. At the end of this paper, there is a detailed presentation of the possibilities of impacting kerf width by the change of the above mentioned parameters of the cutting process.
\end{abstract}

Keywords: feed rate, abrasive flow, water-jet cutting, sample thickness

SAŽETAK • U radu se opisuje proces rezanja MDF ploča abrazivnim vodenim mlazom (WJC) $i$ analiziraju se utjecajni činitelji na širinu propiljka. Istraživan je utjecaj tehničkih i tehnoloških parametara, svojstava materijala i smjera rezanja na širinu propiljka. Rezultati rada daju detaljan prikaz mogućnosti smanjenja širine propiljka promjenom određenih parametara procesa rezanja vodenim mlazom.

Ključne riječi: posmak, protok abraziva, rezanje vodenim mlazom, debljina uzorka

\section{INTRODUCTION \\ 1. UVOD}

Almost any material can be cut by the application of the most used resources, water and stone. The last development makes the method of WJC very efficient. It is avery simple, clean and reliable technology and therefore it becomes an alternative to other methods in various branches. However, there are also limitations of WJC and therefore it should be monitored and its technological process improved. To this purpose we have decided to write this paper (also as a part of VEGA project under the registration number 1/0196/08 titled "Investigation of the process of wood manufacturing by Water Jet Cutting"). Our paper contains specific results from a series of experimental monitoring within the scope of the VEGA title.

WJC technology can be simply described as a process of material cutting by mechanical impact of a liquid on manufactured material. Technology of applied WJC can be divided into two basic groups - cutting by clean native water-jet and cutting by abrasive water jet. Wood processing practice knows cutting by clean native water jet as chipless cutting and abrasive water jet cutting as chip cutting (Bernd, 1993).

\footnotetext{
${ }^{1}$ Authors are assistant professor and assistant at Faculty of Forestry and Wood Sciences, Czech University of Life Sciences Prague, Prague, Czech Republic. ${ }^{2}$ Authors are assistants at Faculty of Wood Sciences and Technology, Technical University in Zvolen, Zvolen, Slovak Republic.

${ }^{1}$ Autori su docent i asistentica Fakulteta šumarstva i drvne tehnologije Češkog sveučilišta bioloških znanosti u Pragu, Prag, Republika Češka.

${ }^{2}$ Autori su asistenti Fakulteta za znanost o drvu i tehnologiju Tehničkog sveučilišta u Zvolenu, Zvolen, Republika Slovačka.
} 


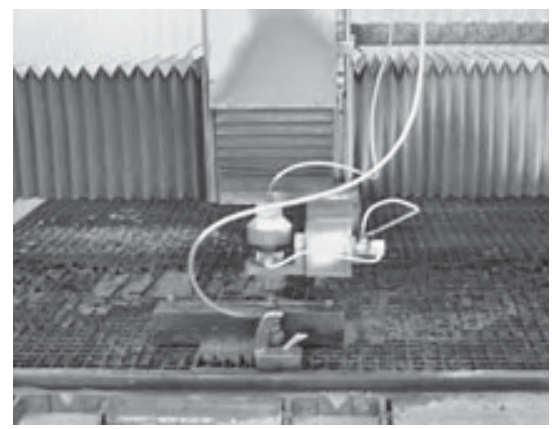

a)

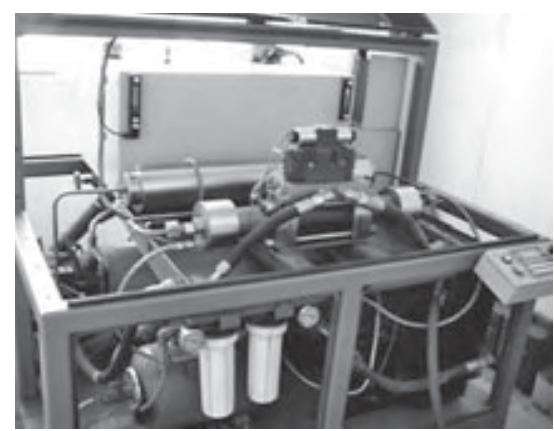

b)

Figure 1 Technological equipment for cutting by water-jet DEMA Ltd.: a) work-table of the equipment b) high-pressure pump (multiplier)

Slika 1. Oprema za piljenje vodenim mlazom DEMA Ltd. a) radni stol, b) visokotlačna pumpa

Technological process uses high pressure and narrow high-speed stream of water (the water pressure around $400 \mathrm{MPa}$ ) as a cutting tool (Maňková, 2000).

Abrasive water jet belongs to more wedges tools with undefined cutting edge (like in grinding) and also decisive mechanism for removal of machined material is similar to the above mentioned method. Cutting wedges are formed with abrasive grains randomly oriented in the beam (Barcík, 2007).

Most equipments for WJC around the world get high pressures by using the multiplier. The principle of high pressures generated by the multiplier lies in the diversity of two tightly linked pistons (Krajný, 1998).

\section{MATERIAL AND METHODS}

\section{MATERIJALI I METODE}

The methodology corresponds to the experimental pursuit (Kvietková, 2010).

MDF boards were used for the WJC experiment. The parameters of the samples were:

- thickness of the test sample: $22 \mathrm{~mm}, 44 \mathrm{~mm}, 66$ $\mathrm{mm}$.

- $\quad$ required width of the test sample: $w=180 \mathrm{~mm}( \pm$ $2.5 \mathrm{~mm}$ )

- required length of the test sample: $l=500 \mathrm{~mm}( \pm 5$ $\mathrm{mm}$ )

- moisture content of the test samples: $w=8 \%( \pm 2 \%)$.

Cutting of samples was done in DEMA Ltd. Zvolen. The equipment was assembled based on components of the American firm FLOW Int. by the firm PTV Ltd. Praha (Figure 1). It consists of a high-pressure pump PTV 37-60 Compact, and a work table with water-jet head WJ 2030 D-1Z supplied by the firm PTV.

Test samples were cut according to the basic cutting plan (Figure 2). Consequently, three cuts were done for each thickness on the samples to eliminate the effect of specific properties of the given sample (Figure 3).

Technical parameters of the devices are similar to states (Barcík, 2010). The experiments were carried out with technical parameters of the equipment:

- cutting liquid pressure: $4000 \mathrm{bar}=400 \mathrm{MPa}$

- abrasive: Australian garnet GMA (grain size 80 $\mathrm{MESH}=0.188 \mathrm{~mm}$ )

- diameter of abrasive jet nozzle: $1 \mathrm{~mm}$
- $\quad$ diameter of water-jet: 0.013 inch $=0.33 \mathrm{~mm}$ - distance of nozzle above the workpiece: $4 \mathrm{~mm}$

- abrasive mass flow: $m_{\mathrm{a}}=250 \mathrm{~g} \cdot \mathrm{min}^{-1}, m_{\mathrm{a}}=350$ $\mathrm{g} \cdot \mathrm{min}^{-1}, m_{\mathrm{a}}=450 \mathrm{~g} \cdot \mathrm{min}^{-1}$

- feed rate: $v_{\mathrm{f}}=600 \mathrm{~mm} \cdot \mathrm{min}^{-1}, v_{\mathrm{f}}=400 \mathrm{~mm} \cdot \mathrm{min}^{-1}$, $v_{\mathrm{f}}=200 \mathrm{~mm} \cdot \mathrm{min}^{-1}$.

The experiments were aimed at investigating:

$w_{\mathrm{t}}$ - kerf width on the side of water-jet input into material (top kerf width): it is the kerf width created by the transfer of abrasive water-jet through material measured on the side of penetration of water-jet into material.

$w_{\mathrm{b}}$ - kerf width on the side of water-jet output from the material (bottom kerf width): it is the kerf width created by the transfer of abrasive water-jet through material measured on the side penetration of waterjet output from the material (Figure 4).

Equipment set for the evaluation:

- personal computer (COMPAQ EVO N 1020v),

- digital camera (Canon PowerShot A520),

- software for working with digital camera (CanonZoom Browser EX 5.0) and for comparative measuring of dimensions (AutoCAD 2007),

- reference scale (Figure 5).

Creation of digital photography of the kerf width with reference scale is illustrated in Fig. 6 and Fig. 7.

\subsection{Measuring of kerf width}

2.2. Mjerenje širine propiljka

Measuring of the kerf width at the output of water-jet from the material becomes more difficult due to

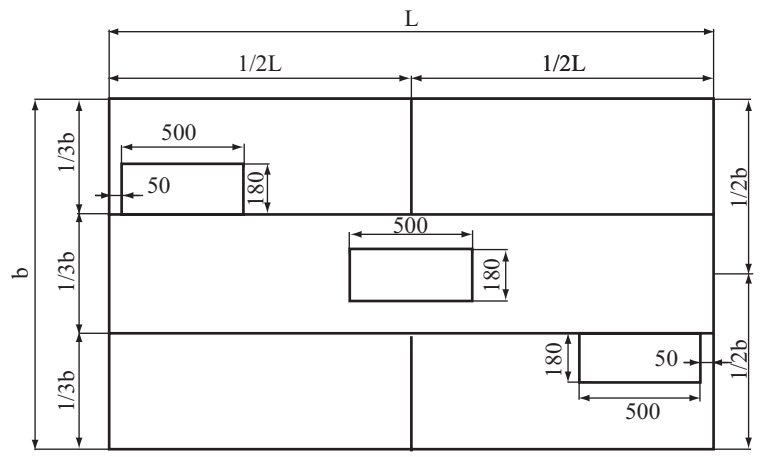

Figure 2 Preparation of test samples

Slika 2. Priprema uzoraka za istraživanje 


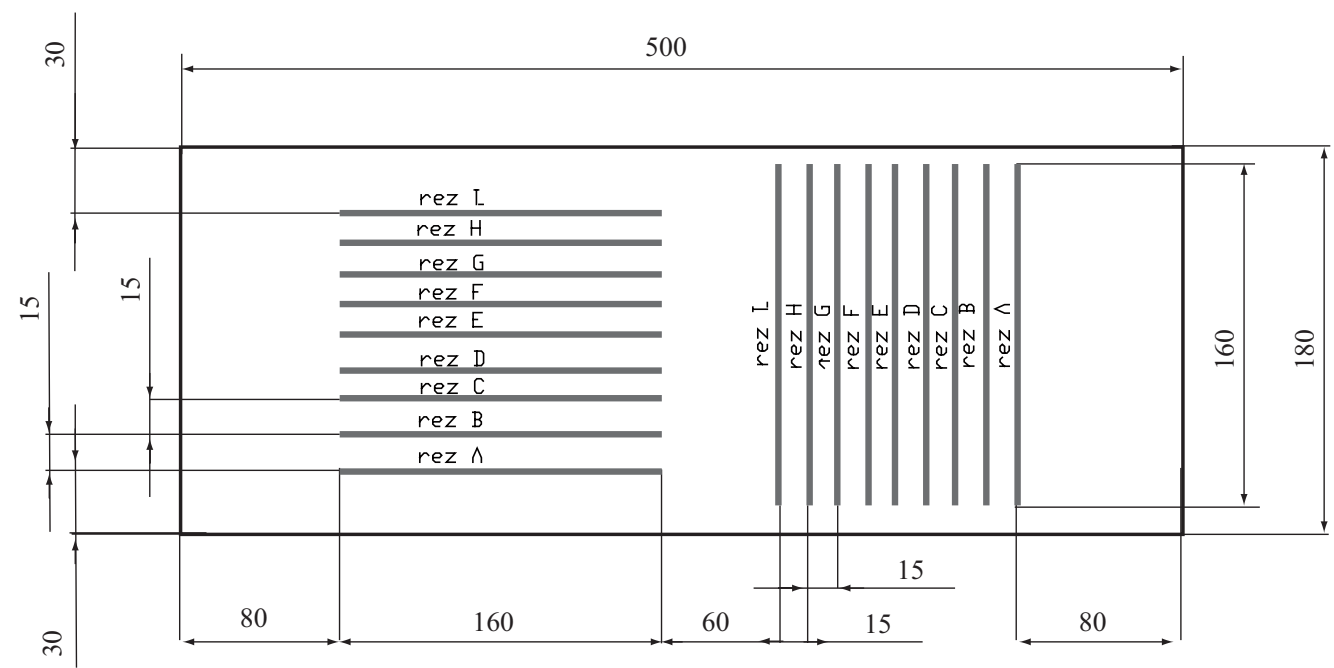

Figure 3 Cutting plan of the test sample Slika 3. Plan rezanja uzoraka

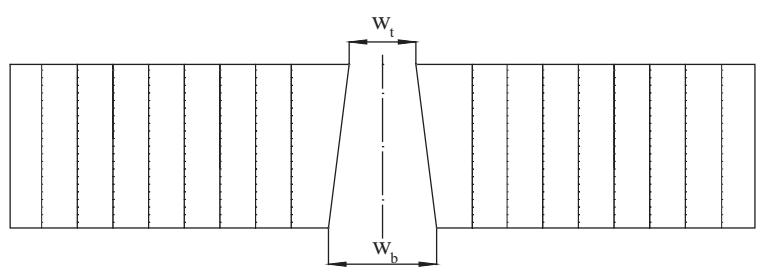

Figure 4 Illustration of the measured kerf width characteristics ( $w_{\mathrm{t}}-$ top kerf width $w_{\mathrm{b}}$ - bottom kerf width)

Slika 4. Prikaz mjerenja širine propiljka $\left(w_{\mathrm{t}}-\right.$ gornja širina propiljka, $w_{\mathrm{b}}-$ donja širina propiljka)

the rippled surface of the cutting edge (see Figure $7 \mathrm{~b}$ ). As for practical use it is important to determine the maximum size of the kerf (in terms of determining the possibilities of the material for further working), the kerf width is measured as the distance between the two most remote parallel tangents placed on the cutting edge, while the evaluated cutting edge length was always $15 \mathrm{~mm}$.

\subsection{Conversion of relative dimensions}

2.3. Promjena relativnih dimenzija

Conversion of relative dimensions was done according to the relation:
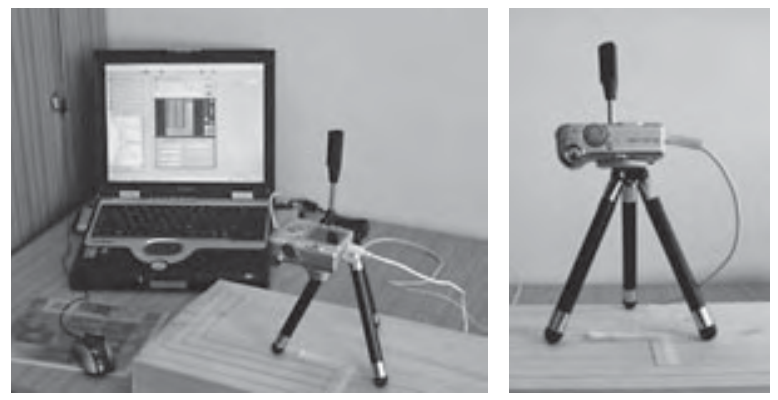

Figure 5 Apparatus for measuring the kerf width Slika 5. Oprema za mjerenje širine propiljka

$$
w_{\mathrm{b}}=\frac{w_{\mathrm{p}} \cdot a}{a_{\mathrm{p}}}
$$

$w_{\mathrm{b}}$ - actual size of the kerf, mm / stvarna širina propiljka, $\mathrm{mm}$

$w_{\mathrm{p}}$ - relative size of the kerf (the size measured in AutoCAD program in digital picture) / relativna veličina propiljka (veličina mjerena u AutoCadu na digitalnoj slici)

$a-$ actual size of the reference scale unit, $\mathrm{mm} /$ stvarna širina propiljka u jedinicama referentne ljestvice, $\mathrm{mm}$

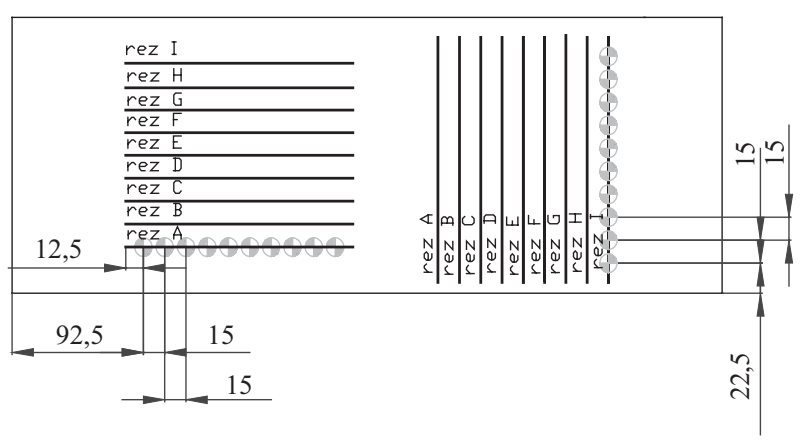

a)

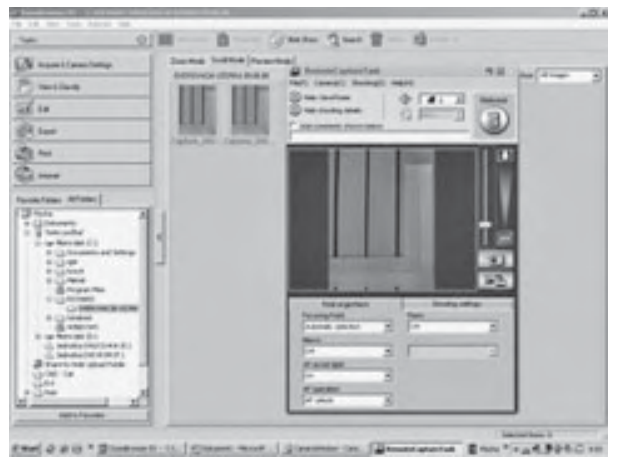

b)

Figure 6 a) Measuring points of the kerf width, b) View at the ZoomBrowser EX 5.0 program window during creation of the digital picture of kerf on the verification sample

Slika 6. a) Mjerna mjesta za određivanje širine propiljka, b) prikaz prozora programa za kreiranje digitalne slike propiljka na kontrolnom uzorku 


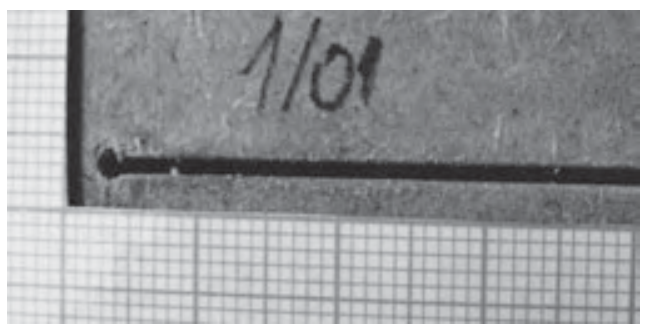

a)

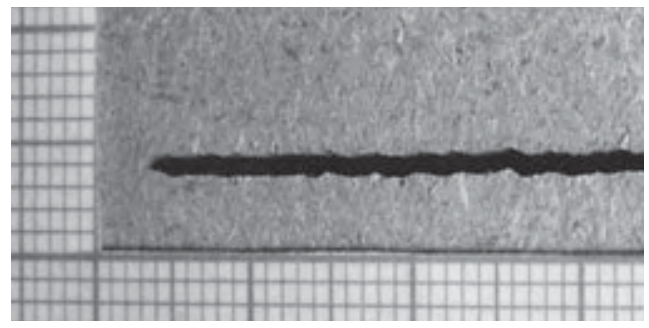

b)

Figure 7 Digital picture of kerf on the MDF board verification sample a) kerf at the input of water jet into material, b) kerf at the output of water jet from the material

Slika 7. Digitalna slika propiljka na kontrolnom uzorku MDF ploče: a) propiljak na ulasku vodenog mlaza u materijal, b) propljak na izlasku vodenog mlaza iz materijala

$a_{\mathrm{p}}$ - relative size of the reference scale unit (the size measured in AutoCAd program in digital picture) (Figure 8) / relativna veličina u jedinicama referentne ljestvice (veličina mjerena u AutoCadu nadigitalnoj slici).

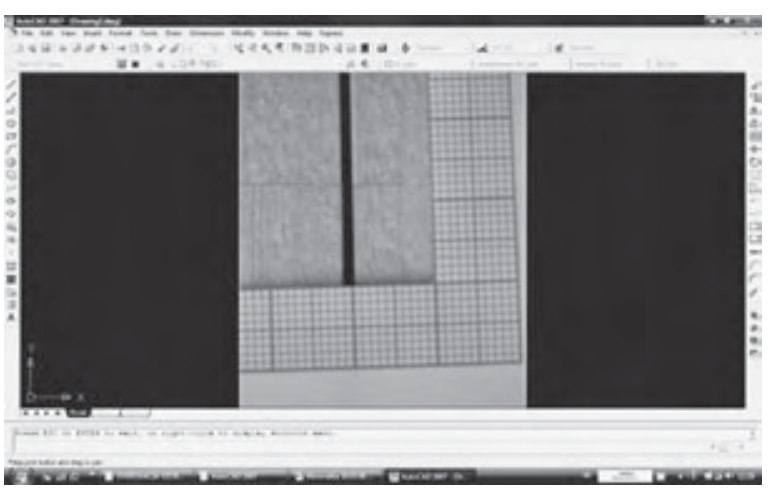

Figure 8 View at the AutoCAD program window during relative measuring of dimensions

Slika 8. Prikaz prozora AutoCaD programa primjerenju relativnih dimenzija propiljka

\subsection{Statistical evaluation}

2.4. Statistička obrada

Using the above procedure we have compiled the file of kerf width input and output values for all samples. Further, these values were evaluated by the software STATISTICA 7.

\section{RESULTS AND DISCUSSION 3. REZULTATI I RASPRAVA}

On the basis of multi-factorial variance analysis, the following sequence of significance of examined factors affecting the kerf width was acquired as presented in Table 1 and 2.

Significance of input factors:

Significance of output factors:

1. cutting direction

1. sample thickness

2. sample thickness

2. feed rate

3. feed rate

3. abrasive flow

4. abrasive flow

4. cutting direction

\subsection{Influence of cutting direction \\ 3.1. Utjecaj smjera rezanja}

The results of the effect of cutting direction and material flow on the kerf width are presented in Table 2 and 3.
The values of the kerf width growth at the input of water-jet into material, while changing the cutting direction from longitudinal to cross-cutting, can be explained by the orientation of particular wood elements. When the material is cut under longitudinal direction, cell elements are oriented by its length dimension identically to tool movement, and at the cross-cutting of the material there are also cells cut. By decreasing the abrasive-jet energy there is higher risk of cell rip in the material.

\subsection{Influence of material thickness \\ 3.2. Utjecaj debljine materijala}

Results of the effect of material thickness on the kerf width are presented in Table 5 and 6.

The greater is the thickness, the higher amount of abrasive particles is gathered in the cut and these particles, apart from their primary effect - cutting of the material, also cause the external effect, which is the widening of the kerf due to washing-out of the material. Increased values of the kerf width in the test samples of higher thickness are significantly influenced by the lag of water-jet caused by gradual loss of its kinetic energy.

The experiment shows that the optimum material thickness is $22 \mathrm{~mm}$. This thickness caused the lowest kerf width values both at the input and output.

\subsection{Influence of feed rate}

\subsection{Utjecaj posmaka}

At the input, the change of the feed rate from 200 $\mathrm{mm} / \mathrm{min}$ to $400 \mathrm{~mm} / \mathrm{min}$ causes values of the kerf width lower by $3 \%$. The change of feed rate from $400 \mathrm{~mm} /$ min to $600 \mathrm{~mm} / \mathrm{min}$ causes an increase of the kerf width by $5 \%$.

At the output, the change in feed rate from 200 $\mathrm{mm} / \mathrm{min}$ to $400 \mathrm{~mm} / \mathrm{min}$ causes an increase of the kerf width by $9 \%$, and the change of feed rate from 400 $\mathrm{mm} / \mathrm{min}$ to $600 \mathrm{~mm} / \mathrm{min}$ causes its increase by $4.9 \%$.

The experiment has shown that the optimum value of the feed rate is explicitly $400 \mathrm{~mm} / \mathrm{min}$, at which the kerf width reaches the lowest dimensions both at the input and output.

\subsection{Influence of abrasive flow \\ 3.4. Utjecaj protoka abraziva}

With the change of the added amount of abrasive from $250 \mathrm{~g} / \mathrm{min}$ to $350 \mathrm{~g} / \mathrm{min}$, the values of the $\mathrm{kerf}$ width have increased by $2 \%$ at the input, and then with an increase of the abrasive amount to $450 \mathrm{~g} / \mathrm{min}$ they have increased by another $2 \%$. 
........ Barcík, Kvietková, Kminiak, Aláč: Optimization of Cutting Process of Medium...

Table 1 Values of multi-factorial analysis (MANOVA) at the input

Tablica 1. Rezultati višefaktorijalne analize (MANOVA) za vrijednosti širine propiljka na ulazu vodenog mlaza u materijal

\begin{tabular}{|l|c|c|c|c|c|}
\hline $\begin{array}{l}\text { Source of oscillation } \\
\text { Uzrok promjene }\end{array}$ & $\begin{array}{c}\text { Sum of squares } \\
\text { Zbroj kvadrata }\end{array}$ & $\begin{array}{c}\text { Degrees of freedom } \\
\text { Stupanj slobode }\end{array}$ & $\begin{array}{c}\text { Dispersion } \\
\text { Rasipanje }\end{array}$ & $\begin{array}{c}\text { F test } \\
\text { F test }\end{array}$ & $\begin{array}{c}\text { P level of significiance } \\
\text { Prazina značaja }\end{array}$ \\
\hline $\begin{array}{l}\text { sample thickness / debljina } \\
\text { uzorka }\end{array}$ & 734.66 & 1.00 & 734.66 & 35417.4 & 0.000 \\
\hline cutting direction / smjer rezanja & 2.58 & 2.00 & 1.29 & 623.00 & 0.000 \\
\hline feed rate / posmak & 1.58 & 1.00 & 1.58 & 762.70 & 0.000 \\
\hline abrasive flow / protok abraziva & 0.09 & 2.00 & 0.60 & 289.40 & 0.000 \\
\hline random factors / slučajni faktor & 1.01 & 2.00 & 0.04 & 21.40 & 0.000 \\
\hline
\end{tabular}

Table 2 Values of multi-factorial analysis (MANOVA) at the output

Tablica 2. Rezultati višefaktorijalne analize (MANOVA) za vrijednosti širine propiljka na izlazu vodenog mlaza iz materijala

\begin{tabular}{|l|c|c|c|c|c|}
\hline $\begin{array}{l}\text { Source of oscillation } \\
\text { Uzrok promjene }\end{array}$ & $\begin{array}{c}\text { Sum of squares } \\
\text { Zbroj kvadrata }\end{array}$ & $\begin{array}{c}\text { Degrees of freedom } \\
\text { Stupanj slobode }\end{array}$ & $\begin{array}{c}\text { Dispersion } \\
\text { Rasipanje }\end{array}$ & $\begin{array}{c}\text { F test } \\
\text { F test }\end{array}$ & $\begin{array}{c}\text { P level of significiance } \\
\text { P razina značaja }\end{array}$ \\
\hline $\begin{array}{l}\text { sample thickness } \\
\text { debljina uzorka }\end{array}$ & 1142.04 & 1.00 & 1142.04 & 10803.40 & 0.000 \\
\hline cutting direction / smjer rezanja & 190.72 & 2.00 & 95.36 & 902.09 & 0.000 \\
\hline feed rate / posmak & 0.27 & 1.00 & 0.27 & 2.54 & 0.111 \\
\hline abrasive flow / protok abraziva & 58.54 & 2.00 & 29.27 & 276.86 & 0.000 \\
\hline random factors / slučajni faktor & 51.92 & 2.00 & 1.96 & 18.52 & 0.000 \\
\hline
\end{tabular}

Table 3 Values of the kerf width at the input depending on the cutting direction

Tablica 3. Vrijednosti širine propiljka na ulasku vodenog mlaza u materijal u ovisnosti o smjeru rezanja

\begin{tabular}{|c|c|c|c|}
\hline $\begin{array}{c}\text { Sample } \\
\text { number } \\
\text { Broj uzorka }\end{array}$ & $\begin{array}{c}\text { Cutting } \\
\text { direction } \\
\text { Smjer rezanja }\end{array}$ & $\begin{array}{c}\text { Arithmetic } \\
\text { mean } \\
\text { Srednja } \\
\text { vrijednost }\end{array}$ & $\begin{array}{c}\text { Standard } \\
\text { deviation } \\
\text { Standardna } \\
\text { devijacija }\end{array}$ \\
\hline 1 & across / poprečno & 1.12 & 0.01 \\
\hline 2 & along / uzdužno & 1.22 & 0.01 \\
\hline
\end{tabular}

Table 4 Values of the kerf width at the output depending on the cutting direction

Tablica 4. Vrijednosti širine propiljka na izlasku vodenog mlaza iz materijala u ovisnosti o smjeru rezanja

\begin{tabular}{|c|c|c|c|}
\hline $\begin{array}{c}\text { Sample } \\
\text { number } \\
\text { Broj uzorka }\end{array}$ & $\begin{array}{c}\text { Cutting } \\
\text { direction } \\
\text { Smjer rezanja }\end{array}$ & $\begin{array}{c}\text { Arithmetic } \\
\text { mean } \\
\text { Srednja } \\
\text { vrijednost }\end{array}$ & $\begin{array}{c}\text { Standard } \\
\text { deviation } \\
\text { Standardna } \\
\text { devijacija }\end{array}$ \\
\hline 1 & across / poprečno & 1.48 & 0.06 \\
\hline 2 & along / uzdužno & 1.43 & 0.06 \\
\hline
\end{tabular}

By changing the added amount of abrasive from $250 \mathrm{~g} / \mathrm{min}$ to $350 \mathrm{~g} / \mathrm{min}$ at the output of water-jet from the worked material, the kerf width values have decreased by $3 \%$. With the change of the amount of abrasive from $350 \mathrm{~g} / \mathrm{min}$ to $450 \mathrm{~g} / \mathrm{min}$, the values have decreased by $6 \%$.

With an increase of the abrasive mass flow to 450 $\mathrm{g} / \mathrm{min}$, the kinetic energy of the particles was consumed by their mutual contact, which generated the secondary effect of washing-out of the material at the input and subsequently the narrowing of the kerf width at the output due to energy loss. However, in comparison with the uniformity of the values at both sides, the value of $450 \mathrm{~g} / \mathrm{min}$ of abrasive mass flow seemed to be optimum.
Table 5 Values of the kerf width at the input depending on sample thickness

Tablica 5. Vrijednosti širine propiljka na ulasku vodenog mlaza u materijal u ovisnosti o debljini uzorka

\begin{tabular}{|c|c|c|c|}
\hline $\begin{array}{c}\text { Sample } \\
\text { number } \\
\text { Broj uzorka }\end{array}$ & $\begin{array}{c}\text { Sample } \\
\text { thickness } \\
\text { Debljina } \\
\text { uzorka }\end{array}$ & $\begin{array}{c}\text { Arithmetic } \\
\text { mean } \\
\text { Srednja } \\
\text { vrijednost }\end{array}$ & $\begin{array}{c}\text { Standard } \\
\text { deviation } \\
\text { Standardna } \\
\text { devijacija }\end{array}$ \\
\hline 1 & 22 & 0.96 & 0.01 \\
\hline 2 & 44 & 1.11 & 0.01 \\
\hline 3 & 66 & 2.29 & 0.10 \\
\hline
\end{tabular}

Table 6 Values of the kerf width at the output depending on sample thickness

Tablica 6. Vrijednosti širine propiljka na izlasku vodenog mlaza iz materijala u ovisnosti o debljini uzorka

\begin{tabular}{|c|c|c|c|}
\hline $\begin{array}{c}\text { Sample } \\
\text { number } \\
\text { Broj uzorka }\end{array}$ & $\begin{array}{c}\text { Sample } \\
\text { thickness } \\
\text { Debljina } \\
\text { uzorka }\end{array}$ & $\begin{array}{c}\text { Arithmetic } \\
\text { mean } \\
\text { Srednja } \\
\text { vrijednost }\end{array}$ & $\begin{array}{c}\text { Standard } \\
\text { deviation } \\
\text { Standardna } \\
\text { devijacija }\end{array}$ \\
\hline 1 & 22 & 1.08 & 0.01 \\
\hline 2 & 44 & 1.26 & 0.01 \\
\hline 3 & 66 & 1.17 & 0.01 \\
\hline
\end{tabular}

\subsection{Economic aspects}

\subsection{Ekonomski aspekt}

At the beginning of the cutting process, it is necessary to decide whether to use water-jet cutting (WJC) or conventional cutting methods. Water-jet cutting is an economical way to cut $2 \mathrm{D}$ shapes in a very wide range of materials with no tooling costs. The unique process of water-jet cutting provides reasonably good edge quality, no burrs and usually eliminates the need for secondary finishing processes. The process also generates no heat so the material edge is unaffected and there is no distortion. Water-jet cutting can cut single or multi-layer materials (Rašner, 2001). 
It is very necessary to take into account the economic aspect of the whole WJC process. WJC should be compared to other cutting techniques in terms of costs and benefits. Costs of WJC assembly and the whole material flow must be monitored and quantified, including here fixed costs, then variable costs (e.g. energy consumption) and also alternative costs related to other (conventional) cutting methods. Another necesary parameter is the production (cutting) time that affects the total capacity and also productivity of an assembly within the material flow. Last but not least, the economic aspect must also take into consideration the amount of waste generated by water-jet cutting compared to conventional cutting methods (Rajnoha and Alač, 2003).

\section{CONCLUSION}

\section{ZAKLJUČAK}

The experiments have shown that the use of water-jet for cutting of agglomerated materials is a suitable method when it is used with the appropriate combination of technical and technological parameters. The most important benefit of this technology is small kerf width compared to other cutting technology. From the viewpoint of equality of kerf width on both sides of worked material, more stabile dimensions of kerf width have been observed when cutting materials in longitudinal direction. From the viewpoint of the used technological parameters, the feed rate of $400 \mathrm{~mm} / \mathrm{min}$ and the abrasive flow of $350 \mathrm{~g} / \mathrm{min}$ have shown to be the optimum. With a thickness exceeding $44 \mathrm{~mm}$, the method becomes less efficient due to the necessary increase of additional work.

\section{REFERENCES \\ 5. LITERATURA}

1. Barcík, Š., 2007: Progresívna metóda obrábania dreva vodným lúčom. (Progresive method of wood manufacturing by water jet). Zvolen: Technická univerzita vo Zvolene, 2007: 3-11.
2. Barcík, Š., 2010: Vplyv hrúbky a smeru rezania na šírku reznej špáry pri rezaní MDF vodným lúčom. (Impact of thickness and cutting direction on the kerf width during the MDF water jet cutting). 09-11.09.2010, Terchová, 33-40.

3. Bernd, K., 1993: Schneiden mit Laserstrahlung und Wasserstrahl. Ehningen bei Böblinger: expert verlag, 1993, 3-93.

4. Fabian, S.; Hloch, S., 2005: Abrasive waterjet process factors influence on stainless steel AISI 304 Macrogeometricalcutting duality. Scientific bulletin, Volume XIX, North University of Baia Mare, Romania, 2005, 261266.

5. Krajný, Z., 1998: Vodný lúč v praxi. (Water jet and its application in practice). Bratislava: EPOS., 1998, 10250 .

6. Kvietková, M., 2010: Analýza faktorov vplývajúcich na kvalitu opracovania drevných materiálov pri rezaní vodným lúčom. (Analysis of factors which impact the quality of manufacturing wood materials by the abrasive water jet cutting), dissertation, pp. 59.

7. Maňková, I., 2000: Progresívne technológie. (Progresive Technologies). Košice: VIENALA., 2000, 63-90.

8. Rajnoha, R.; Aláč, P., 2003: Activity Based Costing - A necessary assumption for the management based on processes, In: Intercathedra 19, Bulletin of plant - economic department of the european wood technology university studies, Poznaň, Pol'sko, 2003, 108-111.

9. Rašner, J., 2001: Economy and management of logistics and distribution systems of wood industrial enterprises. 1/2001/B, pp. 140.

\section{Corresponding address:}

Assist. Prof. ŠTEFAN BARCÍK, Ph.D.

Faculty of Forestry and Wood Sciences

Czech University of Life Sciences Prague

Kamýcká 1176

16521 Prague 6 - Suchdol, CZECH REPUBLIC

e-mail: barcik@fld.czu.cz 